\title{
Government Responsibilities in Community Participation Based Environmental Management for Bali Regional Development
}

\author{
I Nyoman Gede Sugiartha ${ }^{1 *}$, I Made Minggu Widyantara ${ }^{2}$, Nyoman Sujana ${ }^{3}$ \\ Fakultas Hukum Universitas Warmadewa Denpasar ${ }^{1,2,3}$ \\ \{inyomangedesugiartha@gmail.com ${ }^{1}$ \}
}

\begin{abstract}
A good and healthy environment is among the fundamental human rights of every citizen of Indonesia as mandated in Article $28 \mathrm{H}$ of the 1945 Constitution of the country. However, the inability to properly manage the environment contributes to its deteriorating state, hence, the need to increase awareness in environmental protection and management. Also, sustainable environmental protection and management is the responsibility of both the government and the whole community but the government is to ensure that all residents have a good and healthy environment. Additionally, the government could be held accountable administratively when fails to carry out its primary obligations following the community aspirations. Therefore, the purpose of this study was to determine the government's responsibility in environmental management and the legal consequences of its decisions not following community aspiration through participation in Bali. This is normative legal research that involved the application of legislation, conceptual, philosophy, history, comparison cases, and cultural approaches based on the wisdom of the local community. The results show some difficulties encountered in environmental protection and management, thereby causing a decrease in the quality of the environment. Furthermore, perpetrators of environmental destruction through pollution should be held accountable both in civil and criminal law. However, participatory enforcement by integrating the values developed in maintaining and preserving the environment is an ideal form of prudent protection and management in achieving a sustainable regional environment.
\end{abstract}

Keywords: Government responsibility; community aspirations; environmental law; law enforcement.

\section{Introduction}

A good and healthy living environment is the dream of every person in the world, including Indonesian citizens, as stated in Article $28 \mathrm{H}$ of the 1945 Indonesian Constitution. 
Inappropriate environmental management will certainly result in a decrease in the quality of the environment. Therefore, it is necessary to increase the protection and management of the environment, (Najwan 2012). Environmental protection and management aim at realizing sustainable development. To protect and manage the environment in a good and healthy manner, every actor and/or person in charge of a business must obtain an environmental permit under applicable legal provisions. This is stated in the Law on Environmental Protection and Management (UUPPLH) No. 32 of 2009, Government Regulation no. 27 of 2012 concerning Environmental Permits, Minister of Environment Regulation No. 08 of 2013 concerning Procedures for Assessment and Inspection of Environmental Documents and Issuance of Environmental Permit. An environmental permit is a thing that must be owned by the person in charge of business or activity as an effort to supervise the government in protecting and managing the environment (Dewi, 2012). In this case, a legal rule or umbrella is needed as a means or instrument to regulate the rights and obligations of the person in charge of the activity (Kartono 2009). Besides, the law also regulates the legal relationship between the government and citizens (Sutrisno 2011). When the government takes legal action in its capacity as a representative of a legal entity, the action is regulated and subject to the provisions of civil law, Fahmi (2013), whereas when the government acts as an official, the action is regulated and subject to the State Administrative Law and the offender is subject to sanctions according to the level of error (Ramdhan, Yusran, and Darusman 2003).

Thus, certainty in the application of environmental law must be carried out properly and correctly. To maximize law enforcement, it should be supported by appropriate rules and serious implementation by the government (Soemarwoto 1999). However, the problem is that local governments tend to build economic facilities to exploit the environment or natural resources in it and only pursue Regional Original Income, but paying less attention to the carrying capacity of the region's environmental sustainability, and not obeying the rules (Pitana, 2004). Based on the above background, the purpose of this new research is to determine the government's responsibility in managing the environment that is not following the aspirations of the community and to find out the legal consequences for the government for decisions in environmental management that are inconsistent with community participation in Bali.

\section{Research Method}

This research is designed using combined research between normative and empirical law and is supported by several approaches used, such as the statutory approach, conceptual approach, case approach, historical approach, and a comparative approach (Amiruddin and Asikin 2018). The technique of collecting legal materials is carried out using card legal materials. The collection of legal materials using cards is done by reading critically and analytically and taking necessary notes.

This research analysis technique uses a logic flow in normative legal research, which includes several steps. First, describe (explain), at this stage, the description includes the content and structure of positive law. The second is systematization, carried out to describe the content and structure or hierarchical relationship between the related legal rules so that they can be understood properly. The third is the explanation stage, at this stage, an explanation is carried out and there is an analysis of the meaning contained in legal rules concerning legal issues in this study so that the whole forms one logically interconnected unit. 


\section{Results and Discussion}

\subsection{Legal liability on Government in Environmental Management Inconsistent with Community Aspirations}

Taking various actions (including legal actions), the government must rely on the principle of legality. Legal action implies the use of authority and implies an obligation of responsibility. Almost all countries share the responsibility of the state towards citizens or third parties. From a public law perspective, government legal actions are then outlined in and used several legal and policy instruments such as statutory regulations, policy regulations, and decisions (Dewi, 2012). In addition, the government also often uses civil law instruments such as agreements in carrying out government tasks. Any use of authority and application of legal instruments by government officials must have legal consequences, because the purpose is to create legal relations and legal consequences. Moreover, an official is someone who is tasked with carrying out the mandate or taking an action according to his position or exercising authority by his / her responsibilities. Based on the information above, it appears that legal actions carried out by officials in the context of exercising office authority or taking legal actions for and on behalf of the position, then these actions are categorized as legal acts of office.

Regarding the accountability of officials, there are two theories put forward by Kraenburg and Vegting, namely; first, fautes personalles, which is a theory which states that losses to the third party are borne by the official who because of his actions have caused losses, second, fautes de services, which is a theory which states that losses to the third party are borne by the agency of the official concerned. Quoting Logeman's opinion, rights and obligations continue, regardless of changing officials. Based on this information, it is clear that the bearer of the responsibility is a position. Therefore, compensation is also borne by the agency / position, not on the official as an individual. As stated by Kranenburg and Vegting, responsibility is borne by the corporation (agency, position) if the illegal act committed by the official is objective, and the official concerned is not liable if there is no subjective error. On the other hand, the official or employee is held responsible when he commits a subjective error. For other illegal acts, only the representative is fully responsible; he has abused the situation, in which he is his representative, by committing his own immoral actions against the interests of a third party. In such case, the official has committed a subjective error or committed mal-administration. Government accountability regarding decisions that are not in accordance with the aspirations of the community in environmental law has been regulated in the UUPPLH, particularly in Article 91 regarding the Community's Right to Sue in the event that the community is harmed, Article 92 concerning the rights to sue the people who are members of the Environmental Organization and Article 93 UUPPLH gives right for every people in society to be able to file administrative suit against government decisions if:

a. State administrative bodies or officials issue environmental permits to businesses and / or activities that are required to analyze environmental impacts but are not equipped with an analysis document regarding environmental impacts;

b. State administrative bodies or officials issue environmental permit to activities that are mandatory Environmental Management Effort - Environmental Monitoring Effort, but are not equipped with document Environmental Management Effort - Environmental Monitoring Effort);

c. State administrative bodies or officials that issue business and/or activity licenses that are not equipped with environmental permit. 
Criminal law enforcement in environmental law enforcement in UUPLH No. 23 of 1997 is only as ultimum remidium, so the content of the enforcement of criminal sanctions is not dominant. The principle of ultimum remedium in this explanation is less clear. The general explanation is actually an attempt to clarify the meaning of the preamble of a law. The preamble contains philosophical values of a law (Araya 2013). Thus in fact the general explanation is an attempt by the legislators or legislators to reinforce the philosophical values contained in a preamble. The philosophical values in the preamble of a law are concretized in the form of articles of the law (Machmud, 2011).

Basically, the meaning of criminal in a statutory regulation is very important. This has been included in the law on environmental law enforcement with the existence of criminal law provisions that are included in the law on environmental management. Law Number 32 Year 2009 concerning Environmental Management has contained the criminal law provisions in Chapter XV, which consists of 23 Articles, starting from Article 97 to Article 120 UUPPLH. In this regard, the government's responsibility in making decisions that are not in accordance with the aspirations of the community and causing serious loss or injury and / or death can be prosecuted under criminal law. This is regulated in Article 111 and Article 112 of Law no. 32 of 2009 concerning PPLH, Article 111 regulates:

(1) The official issuing an environmental permit who issues an environmental permit without being equipped with Environmental impact assessment or Environmental Management Effort - Environmental Monitoring Effort as referred to in Article 37 paragraph (1) shall be punished with imprisonment for a maximum of 3 (three) years and a maximum fine of IDR 3,000,000,000.00 (Three Billion Rupiah).

(2) Officials issuing business and/or activity permits that issue business and / or activity licenses without environmental permits as referred to in Article 40 paragraph (1) shall be punished with imprisonment for a maximum of 3 (three) years and a maximum fine of IDR. 3,000,000,000. 00 (Three Billion Rupiah).

Article 112 regulates that any authorized official who deliberately does not supervise the compliance of those in charge of a business and / or activity with the laws and regulations and environmental permits as referred to in Article 71 and Article 72, which results in environmental pollution and / or damage resulting in loss of human life, sentenced to imprisonment of 1 (one) year or a maximum fine of IDR 500,000,000 (Five Hundred Million Rupiah).

The regulation in this provision aims to be preventive through supervision and guidance as well as repressive through the application of environmental legal sanctions. Criminal acts regulated in Law No. 32 of 2009 is not a complaint offense but an ordinary offense. As a consequence, investigators are active by directly carrying out their duties to carry out a series of actions such as arresting and detaining the perpetrator without waiting for a complaint from the victim first (Supramono 2013). In carrying out the arrest and detention, civil servant investigators coordinate with investigators of the National Police of the Republic of Indonesia. After the perpetrator has finished the investigation process, then it is brought to the prosecutor's office for prosecution, then the case is submitted to the court to be tried with the aim of determining whether the perpetrator is guilty or not supported by evidence that is legally valid.

In Article 6 paragraph (1) of the Criminal Procedure Code it is known that there are 2 (two) criminal investigators, namely Police investigators and Civil Servant investigators. Police investigators act as general investigators for all criminal acts, while civil servant investigators are special investigators for crimes in certain fields as determined by law (Luthan, 2009). For investigators of criminal acts in the environmental sector, Article 94 
paragraph (1) UUPPLH states, apart from investigating officers of the State Police of the Republic of Indonesia, officials as certain civil servants within government agencies whose scope of duties and responsibilities is in the field of environmental protection and management is given the authority as an investigator as referred to in the criminal procedure law to carry out an investigation of environmental criminal acts. There are two authorized investigators, namely the National Police and Civil Servant Investigators in charge of investigating the environment (PNSLH investigators), (Arief 2008). The Role of Criminal Law in Environmental Management as referred to as the Role of Criminal Law, namely the position (status) of criminal law in carrying out its duties to realize the objectives of criminal law, namely to protect people from crime. Environmental law enforcement can be interpreted as the role of criminal law as an ultimum remedium. The role of criminal law in environmental law must pay attention to the principles including the principle of subsidiarity. In accordance with Sutrisno's opinion, that legal protection as an instrument (tool) of "social control", the function of criminal law can be interpreted as "subsidiarity" meaning that criminal law should only be used if other efforts, namely in the enforcement of environmental law, have been used, administrative law sanctions are not obeyed. , or the violation is committed more than once (Sutrisno 2011). However, besides that, criminal law can also act as a primum remedium, namely as a first attempt at environmental law enforcement, if administrative law and / or civil law are inadequate. Therefore, criminal law is the ultimate weapon for environmental law enforcers (Salim 1997). The application of the principle of subsidiarity that has been carried out by law enforcers (judges) can be seen in the case of pollution in Buyat Bay in Manado with case register number No.284/Pid.B/2005/PN.MDO.

If viewed the Teluk Buyat case above, it is appropriate that the judge sentenced the defendants to freedom. This is because in the law enforcement process, there is no administrative law enforcement. Then from the aforementioned considerations, it states that peace has been achieved in the civil legal process so that the case should stop at the civil legal process and it is not appropriate to proceed to the criminal legal process. Environmental law enforcement that uses criminal law as primum remedium can be seen in the judge's decision with case register number: 1215/Pid.Sus-LH/2016/PN.Pbr. The decision was read on February 20, 2017. The judge's decision, it can be seen that the judge used criminal law as a primum remedium (as the first legal remedy). Primum remedium (criminal law as the first legal remedy), which is the development of the ultimum remedium, which is expected to be able to overcome the problems faced in the use of criminal law. In certain situations criminal law can be used as a first weapon. When other legal instruments, namely civil law and / or administrative law are deemed incapable of overcoming environmental crimes committed by the perpetrator, this is where criminal law acts as primum remedium.

\subsection{Legal Effects on the Government of Decisions in Environmental Management Inconsistent with Public Participation in Bali}

There are several reasons why citizens must receive legal protection from government actions, as a form of responsibility for providing protection to the community, namely:

a) Because in various cases citizens and civil legal entities depend on government decisions, such as the need for permits required for trading, corporate or mining businesses. Therefore, citizens and civil legal entities need legal protection.

b) The relationship between government and citizens does not work on an equal footing, and citizens are on the weak side in this regard. 
c) Various disputes between citizens and the government in favor of the decision, as a government instrument that has unilateral authority in determining interventions in the lives of citizens.

In Indonesia, there are several possibilities for legal protection for the people due to government legal action, depending on the legal instruments used by the government. Commonly used government legal instruments are laws and regulations. Legal protection due to the issuance of statutory regulations is pursued through the Supreme Court, by means of the right of material review, in accordance with Article 5 paragraph (2) of MPR Decree No. III/MPR/2000 concerning Legal Sources and Order of Legislation, which confirms that "the Supreme Court has the authority to examine statutory regulations under the law".

Particularly with regional laws and regulations, cancellation often means spontaneous cancellation, namely cancellation based on the initiative of the organ authorized to declare cancellation, without going through a judicial process. Article 145 of Law no. 32 of 2004 concerning Regional Government, there are the following provisions:

1) Perda is submitted to the government no later than 7 days after it is enacted.

2) The regional regulation as referred to in paragraph (1) which is against the public interest and/or a higher level of legislation may be canceled by the government.

3) The decision to cancel the Perda as referred to in paragraph (2) shall be stipulated by a Presidential Regulation no later than 60 days from the receipt of the Perda as referred to in paragraph (1).

4) No later than 7 days after the decision to cancel the regulation as referred to in paragraph (3), the regional head must stop the implementation of the Perda and then the DPRD together with the regional head revokes the said Regional Regulation..

5) If the province/regency/city cannot accept the decision to cancel the regional regulation as referred to in paragraph (3) with reasons that can be justified by statutory regulations, the regional head may file an objection to the Supreme Court.

6) If the objection as referred to in paragraph (5) is granted partially or in full, the decision of the Supreme Court states that the Presidential Regulation is null and has no legal force.

7) If the Government does not issue a Presidential Regulation to cancel the Perda as referred to in paragraph (3), the Perda shall be declared valid.

Based on these provisions, it appears that the regional level laws and regulations have a mechanism of judicial rights that is different from the statutory regulations at the central level, namely that they are taken through government channels in the form of postponement or cancellation, before being pursued through the Supreme Court. Legal protection resulting from the issuance of a decision is pursued through two possibilities, namely administrative law court and administrative legal remedies. There is a difference between administrative law court and administrative effort, the word judiciary shows that this concerns the judicial process in government through independent agencies.

Based on Law no. 5 of 1986 concerning State Administrative Courts legal protection due to issuance of decisions can be pursued in two ways, namely through administrative efforts and through the PTUN. Article 48 affirms as follows:

1) In the event that a State Administration Agency or Official is authorized by or based on statutory regulations to resolve certain state administrative disputes administratively, the state administrative dispute must be resolved through available administrative efforts.

2) The new court has the authority to examine, decide and settle state administrative disputes as referred to in paragraph (1) if all administrative measures concerned have been used. 
There are four elements of sanctions in state administrative law, namely tools of power, being public law, used by the government, and as a reaction to non-compliance. In terms of its objectives, in state administrative law there are two types of sanctions, namely reparatory sanctions and punitive sanctions. Reparatory sanctions are sanctions that are given as a reaction to a violation of norms, aimed at returning to the original condition before the violation occurred. Meanwhile, punitive sanctions are sanctions that are solely intended to punish someone. In addition, there are also what are called regressive sanctions, namely sanctions that are applied as a reaction to non-compliance.

\section{Conclusion}

Based on the results of the analysis above, it can be concluded that the government's responsibility for environmental management which is inconsistent with the aspirations of the community can be in the form of administrative, civil or criminal responsibility. Government accountability from administration based on the decision of Law no. 9 of 2004 concerning Amendments to Law no. 5 of 1986 concerning PTUN. Civil liability is based on Article 1365 of the Civil Code, which basically contains: "every act violating the law, which brings harm to another person, obliges the person who due to his wrongdoing the loss, compensates the loss." This provision has undergone a shift in interpretation, as seen from some jurisprudence. Concepts that set out criteria for legal interests that are violated by the government can be challenged. In this regard, the government's responsibility in making decisions that are not in accordance with the aspirations of the community and causing serious loss or injury and / or death can be prosecuted under criminal law. This is regulated in Article 111 and Article 112 of Law no. 32 of 2009 concerning PPLH. Legal consequences for the government for decisions in environmental management that are inconsistent with community participation in Bali. UUPPLH No. 32 of 2009, provides legal channels, administration, civil law channels and criminal law channels, settlement outside court proceedings as regulated in Article 85, Article 86 and in court related to compensation, environmental restoration and other actions. Legal disputes in Bali can also be resolved based on the Bali Provincial Regulation, related to the legal consequences of the government in terms of decisions not in accordance with the aspirations of the community in environmental law, the contested rights are regulated in Article 91 and Article 92 UUPPLH No. 32 of 2009, concerning the right to sue the people who are members of the Environmental Organization and Article 93 of the UUPPLH gives the right of everyone in society to file an administrative lawsuit against a government decision.

\section{References}

[1] Amiruddin and Zainal Asikin. 2018. Pengantar Metode Penelitian Hukum. Jakarta: Rajawali Pers.

[2] Araya, Yulanto. 2013. "Penegakan Hukum Lingkungan Hidup Di Tengah Pesatnya Pembangunan Nasional.” Jurnal Legislasi Indonesia 10(1).

[3] Arief, Barda Nawawi. 2008. Bunga Rampai Kebijakan Hukum Pidana. Jakarta: Kencana Prenada Media Group.

[4] Dewi, Dyah Adriantini Sintha. 2012. "Konsep Pengelolaan Lingkungan Hidup, Menuju Kemakmuran Masyarakat.” Jurnal Fakultas Hukum 1(1). 
[5] Fahmi, Sudi. 2013. "Asas Tanggung Jawab Negara Sebagai Dasar Pelaksanaan Perlindungan Dan Pengelolaan Lingkungan Hidup." Jurnal Hukum 18(2).

[6] Kartono. 2009. "Penegakan Hukum Lingkungan Administratif Dalam UndangUndang Perlindungan dan Pengelolaan Lingkungan Hidup." Jurnal Dinamika Hukum (3).

[7] Luthan, Salman. 2009. “Asas Dan Kriteria Kriminalisasi.” Jurnal Hukum 16(1):8.

[8] Machmud, Syahrul. 2011. Penegakan Hukum Lingkungan Indonesia. Yogyakarta: Graha Ilmu.

[9] Najwan, Ohni. 2012. "Perlindungan Dan Pengelolaan Lingkung-an Hidup Dalam Perspektif Hukum Islam.” Jur-Nal Ilmu Hukum 2(4).

[10] Pitana. 2004. Memperjuangkan Otonomi Daerah: Mencegah Sandyakalaning Pariwisata Bali. Denpasar: Pustaka Bali Post.

[11] Ramdhan, Hikmat, Yusran, and Dudung Darusman. 2003. Pengelolaan Sumber Daya Alam Dan Otonomi Daerah: Perspektif Kebijakan Dan Evaluasi Ekonomi. Alqaprint Jatinangor.

[12] Salim, Emil. 1997. Mengenal Hukum Lingkungan Indonesia. edited by G. P. Soemartono. Jakarta: Sinar Grafika.

[13] Soemarwoto, Otto. 1999. Analisis Mengenai Dampak Lingkungan. Yogyakarta: Gadjah Mada University Press.

[14] Supramono, Gatot. 2013. Penyelesaian Sengketa Lingkungan Hidup Di Indonesia. Jakarta: Rineka Cipta.

[15] Sutrisno. 2011. "Politik Hukum Perlindungan Dan Pengelolaan Lingkungan Hidup." Jurnal Hukum 18(3):444-64. 